\title{
Politique africaine de la France: arrêtons le massacre
}

\author{
François-Xavier Verschave ${ }^{1}$
}

\begin{abstract}
The Rwandese genocide dramatically reveals the senseless nature of French policy in Africa-determined by personal relationships, speculation, and corruption. As the "reserved domain" of the French President for the past 35 years, French policy on the African continent has been dominated by personal relationships between the French President and his African counterparts, the military lobby, the francophone lobby (Fachoda Syndrome), and some French enterprises (ELF, Bouygues, Bolloré), all of which have escaped from any democratic control.

Hence in Rwanda, France armed, financed, and trained a regime that exhibited Nazi-like features with its guard presidential, militia, hatred propaganda (Radio Mille
\end{abstract}

Collines), pogroms throughout 1992, and finally the genocide of April 1994. Since the coming into power of the Rwandese Patriotic Front (RPF)-perceived as proAnglo-Saxon because of its link with Uganda-France has multiplied its efforts to fill the (pro-French) vacuum left in the region, by calling upon the Zairean dictator Mobutu to "stabilize" the region, and by selling the usual military "package" (arms and training) to the Sudanese regime.

[The author is calling upon] the French population and the international community to mobilize against the present French policy in Africa, and identifies three French organizations that are currently lobbying for a human, pro-democratic and non-secretive French policy in Africa.

\section{Le génocide rwandais, révélateur d'une politique insensée}

La France a soutenu au Rwanda un régime en pleine dérive nazie, qui a installé à partir de 1990 l'équivalent des SS (la Garde présidentielle), des SA (les milices de tueurs) et une propagande radiophonique de masse sur la radio officieuse des Mille Collines. Surnommée Radio-Machette, elle est le principal responsable, impuni, des massacres comme de l'exode mortel. Dès 1992, des pogromes, prémisses ou répétitions du génocide, ont été organisés par le Président Habyarimana, sa femme et son clan-depuis une maison appelée par dérision la «synagogue.»

La France a financé, armé et formé la Garde présidentielle tribale qui, avec ses excroissances miliciennes, a exécuté le génocide. Au camp de Bigogwe, tandis que des instructeurs français formaient les commandos rwandais, de pleins camions amenaient chaque jour un chargement de civils destinés à être torturés et exécutés, puis repartaient avec les corps.

François-Xavier Verchave is the general secretary of SURVIE, a French NGO lobbying for an indepth reform of French Official Public Development.
Toutes ces informations s'accumulaient à l'Elysée et Matignon plus d'un an avant les événements d'avril 1994: on a pourtant continué d'envoyer des armes aux responsables des tueries, bien après leur déclenchement. Paris a accueilli, avec les honneurs et l'argent de la Coopération, Mme. Agathe Habyarimana et certains des principaux instigateurs des massacres.

La France n'était pas au Rwanda en 1959, elle n'en connaissait rien: elle y est venue très progressivement, par les affaires et la francophonie. Puis elle s'est prise au jeu d'évincer l'ancien colonisateur belge-comme au Zaïre, comme elle l'a fait de l'Espagne en Guinée équatoriale, ou du Portugal en Angola-dans la perspective d'une sorte d' «Afrique latine," d'une Françafrique de la complaisance contre le Commonwealth du business, plus distant politiquement.

En bordure du Zaire, le Rwanda était devenu un relais pour tous les trafics qu'autorise l'anarchie savamment entretenue de ce pays-continent (or, pierres précieuses, drogues, armes). Scellé par un accord secret de défense, l'alliance franco-rwandaise a pris la tournure familière, puis familiale, qui caractérise les relations entre le chef $d^{\prime}$ Etat français et ses homologues africains. Un trait poussé jusqu'à la caricature par Jean-Christophe Mitterrand, le fils du Président et son conseiller aux affaires africaines jusqu'en 1992, qui s'est fait l'intermédiaire dévoué des familles Habyarimana, Bongo, Eyadema, Biya, ..

Sous ce «régime» économique et politique, la Françafrique est en perte de vitesse, face notamment au Nigéria, à l'Afrique du Sud et à certains pays $d^{\prime}$ Afrique de l'Est. Les chefs d'Etat des pays du "champ» perdent de leur prestige et, de plus en plus, de leur légitimité vis-à-vis de populations assaillies de difficultés. Mais, jusqu'au début de 1994, la parité du franc CFA et les accords de défense avec la France constituaient en quelque sorte des assurances tous risques contre l'irresponsabilité économique et politique. La crédibilité de cette protection était en jeu au Rwanda, et la France était mise au défi d'en prouver la fiabilité. ${ }^{2}$

Dans ces conditions, Jean-Christophe Mitterrand ne pouvait que répondre favorablement à l'appel au secours, en 1990, du président rwandais Juvénal Habyarimana. Sur un simple coup de téléphone au 2 rue de l'Elysée, il fut décidé d'envoyer plusieurs centaines de parachutistes français pour contrer la rébellion du Front Patriotique Rwandais. Celui-ci avait tous les défauts: il était animé par des Rwandais exilés en pays anglophone (l'Ouganda de Yoweri Museveni), 
soupçonné donc de «faire le jeu des Anglo-saxons" (le syndrome de $\mathrm{Fa}$ choda); surtout, il échappait à l'influence des "Messieurs Afrique. ${ }^{3}$ " Une fois décidé cet engagement aux côtés d'une dictature clanique, il ne sera plus possible de retirer le doigt de l'engrenage. La direction microcéphale de la politique franco-africaine est en effet incapable de faire appliquer ses contre-ordres: le soutien tardif, et peutêtre sincère, aux accords de paix d'Arusha, a été saboté par des militaires français qui, comme au temps de l'Algérie, avaient épousé les thèses des extrémistes.

\section{Pourquoi s'arrêter en si bon chemin ?}

Loin de tirer les leçons du carnage rwandais, les mêmes géopoliticiens s'inquiètent maintenant du "vide» causé par l'effondrement du clan Habyarimana. On multiplie les appels, délégations et invitations envers le maréchal zaïrois Mobutu, auquel on demande de prendre le relais et de «stabiliser» la région. Celui qui ruine consciencieusement le Zaïre depuis plusieurs décennies et l'enfonce dans le chaos, celui qui autorise un début de génocide des kasaiens au Katanga, redevient en effet, pour la Françafrique néo-coloniale, le meilleur champion du combat francophone contre l' «anglo-saxon» Museveni. Il s'agit ainsi de montrer à tous les régimes autoritaires protégés par des accords de défense que la garantie de la France ne s'arrête pas à une bavure, fút-elle gigantesque. On est d'ailleurs en train de vendre le même "paquet» de services militaires au régime intégriste soudanais, pour lui permettre de mieux massacrer la résistance sudiste ... adossée à l'Ouganda.

L'opération Turquoise survient alors comme une démonstration de force: il s'agissait de urouler les mécaniques» dans les deux sens du terme (tester un dispositif logistique, affirmer un rôle de parrain régional). On a utilisé l'émotion suscitée par le génocide-mais on s'est bien gardé d'en arrêter les responsables et de faire taire «Radio-machette.»

\section{Favoriser un rappel à la raison démocratique}

L'abominable exemple rwandais, le retour en grâce de Mobutu et l'alliance soudanaise ne sont que les cas extrêmes d'une politique franco-africaine qui s'exerce avec les mêmes errements au Togo, au Cameroun, au Gabon, au Congo, au Tchad, ... La direction de cette politique relève depuis 35 ans du "domaine réservé» présidentiel. Confinée rue de l'Elysée, dans la cellule franco-africaine, elle échappe à tout contrôle démocratique, à tout débat sur ses objectifs et ses méthodes. $N^{\prime} y$ associant pas le peuple français, elle y a encore moins associé les peuples africains: c'est devenu une affaire entre chefs $d^{\prime}$ Etat.

L'obscurité a permis la prolifération de l'affairisme, de la corruption (en France et en Afrique) et des coups tordus. Le mauvais usage des crédits, le détournement de l'aide publique au développement, ainsi que des rentes agricoles et minières, ont contribué à endetter les pays du champ de la coopération française, et à dégrader leurs économies. Les avantages du pouvoir $d^{\prime}$ Etat n'en sont devenus que plus désirables: tous les moyens sont alors permis pour les conquérir et les défendre, à partir d'une base sociale de plus en plus réduite au clan présidentiel.

Cette évolution aberrante s'est accompagnée de la montée en puissance, en France, de groupes d'intérêts et de lobbies, que le pouvoir a utilisés, tolérés, ou laissé prospérer-au point qu'aujourd'hui il ne les contrôle plus guère. La politique africaine de la France est devenue un champ clos où rivalisent quelques dizaines de clans, corporations et réseaux: ceux des anciens responsables Afrique de l'Elysée (de Jacques Foccart à Jean-Christophe Mitterrand); ceux de tel ou tel ministre ou député (ancien ou actuel); Elf (qui cogère pratiquement trois pays africains); quelques entreprises très implantées, comme Bouygues ou Bolloré; à quoi s'ajoute le dangereux lobby militaro-africaniste. Sur le terrain, les stratégies des uns et des autres s'encastrent dans un désordre ravageur. La déresponsabilisation et la démoralisation des acteurs de ce système sont telles qu'on pourrait le comparer à la centrale nucléaire de Tchernobyl: n'importe quel accident devient possible.

La crédibilité des institutions démocratiques françaises est en jeu: incontrôlé, l'exécutif est débordé par les groupes d'intérêts. Les fondementsmêmes de la République sont atteints: comment condamner le milicien Touvier ou le gestapiste Barbie, puis réserver le meilleur accueil aux instigateurs du génocide de près d'un million de personnes ? comment célébrer la Résistance à Hitler et révérèr la force brute d'un Mobutu ?

Pour les citoyens français, il est urgent de mieux comprendre les aberrations de cette politique, et d'exiger qu' elle soit rappelée à la raison démocratique: le dispositif actuel compromet gravement l'image de leur pays et $l^{\prime}$ avenir de ses relations avec les peuples africains. A l'étranger, c'est un devoir de manifester une nette réprobation à ces dérives ubuesques-plutôt que le lâche soulagement d'un «abandon" de l'Afrique au seul pays occidental qui veuille s'en occuper. Le monde entier perdrait à cet abandon. Et la France est suffisamment inquiète de son image internationale pour qu'une pression extérieure l'encourage à plus de pondération. Ce fut sûrement le cas lors de l'opération Turquoise.

\section{Des points d'appui dans la société française}

Signalons-en trois:

- Une quinzaine d'organisations non-gouvernementales françaises viennent de constituer le «noyau dur" d'une "Coalition pour un contrôle démocratique de la politique africaine de la France."

- Une trentaine de spécialistes, experts et universitaires, des questions de cooperation et de développement, ont créé au début de 1994 un Observatoire permanent de la Coopération française. ${ }^{5}$ Son premier rapport annuel comporte un chapitre sur La politique de la France au Rwanda (1973-1994). 
- L'association civique Survie mène depuis onze ans une campagne pour une réforme en profondeur du système français de coopération, qui délègue beaucoup plus la mise en oeuvre de l'APD à un dispositif stimulant et coordonnant les initiatives de la société civile. Une proposition de loi en ce sens, initiée par Survie, a été cosignée parles $3 / 4$ des députés. Mais sa mise à l'ordre du jour est freinée par les logiques contraires qui animent encore la majorité des «décideurs" de la politique francoafricaine.

\section{Notes}

1. Ouvrage collectif paru sous le pseudonyme "Claude Marchants: Nord-Sud, de l'aide au contrat. Pour un développement équitable, Syros, Paris, 1991. Co-auteur, avec Anne-Sophie Boisgallais, de L'aide publique au développement, Syros, Paris, 1994. Auteur de Libres leçons de Braudel. Passerelles pour une société non-excluante, Paris, Syros, 1994.

2. «ll suffit d'écouter le silence gêné des dirigeants $d$ 'Afrique francophone face $d$ cette tragédie [rwandaise]. Un silence assourdissant dont la signification est limpide: tous ou presque redoutent comme un précédent une victoire des opposants du Front Patriotique Rwandais. Il y a quelques jours à Paris, les ambassadeurs de ces mêmes pays réunis toutes portes closes autour de responsables français l'ont clairement fait savoir : quelle difference y a-t-il entre le FPR et les Casamançais basés en Guinée-Bissau, les Touaregs repliés en Libye, les Togolais implantés au Ghana ou les Tchadiens installés au Soudan? Aucune, d leurs yeux. Qu'ils représentent des régimes autoritaires vieillissants ou de jeunes démocraties, les excellences se sont montrées unanimes : pas question d'apporter aux rebelles du Front la moindre caution. \&La France nous a imposé la dévaluation, qu'elle empéche au moins la déstabilisation», s'est écrié un ambassadeur» (François SOUDAN, in Jeune Afrique du 02/06/94).

3. Pour reprendre le titre Ces Messieurs Afrique de la galerie des portraits des éminences grise de la Françafrique, dressée par Antoine Glaer et Stephen Smith, CalmannLévy, Paris, 1992.

4. Contacts: Jean-Marie Fardeau, Agir ici, 14 passage Dubail, 75010-Paris, Tél. 33.1.40. 35.07.00, Fax 33.1.40.35.06.20; ou Sharon Courtoux, Survie, 57 avenue du Maine, 75014-Paris, Têl. 33.1.43.27.03.25, Fax 33.1.43 .20.55.58.

5. c/o CFSI, 8 rue de Dobropol, 75017-Paris. Contact: Laurent Barraud. Tél. 33.1.40. 55.09.33. Fax 33.1.45.74.22.48.

\section{Abstract}

\section{The Repatriation of Rwandan Refugees: $A$ Veritable Dilemma}

This paper explores the problematic repatriation of Rwandan refugees and attempts to demonstrate that their return, in the absence of a durable peace, is not a definitive solution.

The situation in Rwanda has been extremely volatile since the killing of Rwanda's former President in April 1994. Genocide upon genocide occurs right now. About 2.5 milion Rwandans have fled the country. Everybody asks the same question: "why?" The response from a majority of external observers is unanimous: it is a tribal conflict inspired by longstanding rivalry between the Hutu and the Tutsi.

However, behind these simplistic affirmations hides another reality. The war in Rwanda is, above all, a struggle for power. The elites of the country parade tribalism in order to justify the legitimacy of this power struggle. The stereotype of Hutu and Tutsi opposition is not sufficient to explain the Rwandan tragedy.

If there is to be a durable peace in Rwanda, the most fundamental condition is the way in which power is to be shared. Consequently, the question of repatriation within the Rwandan context remains a veritable dilemma.

Paradoxicaly, while many Rwandans are still fleing, some refugees are already returning to this country consumed by violence and war. How can this phenomenon be explained? Two factors explain this premature return. The first is the dismal economic situation in the host countries, and the second is the socio-cultural nature of the Rwandan society.

The fact that some Rwandan refugees have returned voluntarily does not mean that this is the best solution for them and that they are not in danger. Many had no choice, because the miserable situation in the refugee camps forced them to go back home

Boniface Shally B. Gachuruzi,Ph.D, is a researcher at CRS, York University. before the end of the conflict. They returned home to flee cholera and hunger which claimed many victims. Remaining in the overcrowded refugee camps would mean risking death by disease; returning home would also mean risking death in the ongoing conflict. For many, the only choice is to return and die on their family soil.

It is important to stress that many Africans would prefer to die rather than leave their homeland. The reason for this is that their ancestors lie in the family soil. The African community is constituted by the living and the dead and both have a specific role to play in the community.

According to the renowned African author, Camara Lay, the dead do not die. They are in the field, in the river, in the forest;. they are in the family soil and it would be cruel to forsake them. In the same vein, Yohannes Gabressellasie states that, in the African context, the sense of attachment which refugees have towards their homeland is strong. As some researchers note:

Return migration is important in Africa and is explained to a large extent by the social and cultural traditions (...). The cultural factors, however, in most of Africa play a decisive role. To most West Africans the ancestral village remains home. ${ }^{1}$

Even if it is possible to solve the problem of civilian refugees repatriation through diplomatic negotiations or through a national program of reconciliation, the repatriation of 20,000 Rwandan soldiers will not be so straightforward. Indeed, it is no secret that the dismal situation in Rwanda is largely the responsibility of the former government and especially the army. How will the Rwandan Patriotic Front accept the repatriation of their worst enemies?

The politicians know that if these soldiers do not return now, they may attack at any time. What they do not know is how to accomplish their return 